Sandra Fortuna

UDC 78.085

Conservatory of Music "Licino Refice" of Frosinone doi:10.5937/ZbAkUm1705120F Music Education Department

Pedagogy of Music

Italy

\title{
Embodiment, Sound and Visualization: a Multimodal Perspective in Music Education
}

\begin{abstract}
Recently, many studies have emphasized the role of body movements in processing, sharing and giving meaning to music. At the same time, neuroscience studies, suggest that different parts of the brain are integrated and activated by the same stimuli: sounds, for example, can be perceived by touch and can evoke imagery, energy, fluency and periodicity. This interaction of auditory, visual and motor senses can be found in the verbal descriptions of music and among children during their spontaneous games. The question to be asked is, if a more multisensory and embodied approach could redefine some of our assumptions regarding musical education. Recent research on embodiment and multimodal perception in instrumental teaching could suggest new directions in musical education. Can we consider the integration between the activities of body movement, listening, metaphor visualization, and singing, as more effective than a disembodied and fragmented approach for the process of musical understanding?
\end{abstract}

Keywords: Embodied, multimodal learning, visualization, music education, body movement

\section{Introduction}

Until recently research on perception has considered our sensory modalities as being separate and activated by specific physical stimuli; that is to say, sight, hearing, touch, and our sense of space are activated by images, sounds, pressure and body movements respectively. The theory of our senses being isolated does not take into consideration the fact that making sense of an environment is not a static and objective process, but arises from an integration of different senses. The assumption is that each sense is not isolated, but some multimodal inputs bring simultaneous information about 
the same event or object. Sounds, for example, can be perceived by touch and can evoke imagery, energy, fluency and periodicity. This synesthetic interaction of auditory, visual and motor senses can be found in verbal descriptions of music (Zbikowski, 2008); or it can give meaning to a musical experience.

At the same time this synesthesia can be observed among children in their spontaneous games, in which the movement of an object can be interpreted by the voice, and the features of a sound can be transposed into a sign or a gesture. Nevertheless, traditional accounts of instrumental pedagogy tend to follow disembodied teaching modalities: verbal instructions, rehearsals, reading notations, but no movement. The aim of this article is to understand if recent research regarding multimodal perception, in which body movement, visualization, touch and movement are integrated, could lead to new directions in musical education in order to make the teaching of music closer to a child's natural method of learning.

The questions to be asked are, if a more multisensory and embodied approach could contribute to expanding our ideas, and if it could redefine some of our assumptions regarding musical education. Recent research on embodiment and multimodal perception in instrumental teaching could suggest new directions in musical education. Can we consider the integration between the activities of body movement, listening, metaphor visualization, and singing as more effective than a disembodied and fragmented approach to the process of musical understanding?

\section{Background}

Recently, many studies have emphasized the role of the body as a mediator between music and cognition in musical understanding (Leman 2008, 2010a). This standpoint holds that a basic form of musical meaning is action-based, and is radically entwined with the level of motor knowledge of the listener or performer, so the body should be considered the natural mediator between the mind and the physical musical environment.

Other studies are focused mainly on the function of body movements in processing, sharing and giving meaning to the music. Maes \& Leman (2013) investigated in which way expressive body movement, paired with music, can modulate children's perception of musical expressiveness. By the analysis of the arm movements of listeners it was found that there is a correlation with the velocity of the movement of the player's shoulders, sharing the same corporeal intentionality (Leman et al. 2009); Phillips-Silver \& Trainor $(2005,2007)$ on the other hand, demonstrated an early cross-modal interaction between body movement and auditory encoding of musical rhythms in infants and adults; Eerola, Luck \& Toiviainen (2006) investigated pre-schoolers' corporeal synchronization 
with music. Kozak (2015) argues that the movement of the listener's body through space and time can represent a model for the way they process music.

According to a phenomenological perspective, the role of the body was also underlined in the past by Merleau-Ponty (1962), who considered the body as a primary access to the world and to objects in general. The philosopher explained as follows:

"Knowledge gained through bodily experience is not, however, 'objective knowledge' but, rather, contributes to one's unique subjective understanding of some particular matter". (Merleau-Ponty 1962 p. 140)

Merleau-Ponty assumed that what we learn is relative to our body's interaction with the world around us. Through our active corporeal experiences, we create cognitive, physical, emotional, and spiritual meanings of the motion and changes in our surroundings.

In music education, the role of body movements has been studied recently by various authors, with the purpose of emphasizing the relationship between musical features and body movements during the process of learning. Recently, research has also focused on the effects of body movement in the development of musical knowledge and instrumental skills (Juntunen, Westerlund 2001; Juntunen, Hyvonen 2004; Abril 2011) and on expressive musical performance (Davidson 2012). Expressive communication with the instrument is also investigated on the basis of embodied music cognition framework (Nijs et al. 2013).

According to other studies, the role of body movement as a means of processing and shaping musical meaning can have a close relation with the process of non-verbal symbol formation, as a visual metaphor of the sound features. The cross-modal correspondence between sound and visualization was analysed first by Werner (Werner \& Kaplan 1963), who emphasized the role of symbolic vehicles e.g. lines or drawings, and their cognitive functions. In the same study he argued that symbols are closely connected to the body and its sensorimotor pattern: "[...] because of their relative closeness to the symbolizer, [they] are conducive to representation of referents that could be considered as paradigmatic of genetically early stages of symbolization". (1963 p. 335)

More studies have analysed the external graphic visualizations of pieces of music, drawn by trained or untrained participants. Bamberger $(1982,1991)$ considers symbols such as invented notations a means to access children's musical communication and cognition. To understand the children's notational strategies, researchers investigated the ways in which children represent different musical excerpts (songs, rhythm patterns and children's compositions) with their own invented notations (Bamberger, 1991; Barrett, 2002; Davidson \& Scripp, 1988; Gromko, 1994; Upitis, 1987, 1992; Verschaffel, Reybrouck, Janssens \& van Dooren 2009). 
Other studies focuse instead on the cross-modal correspondence between sound features and graphic visualization. Research has shown that dimensions of auditory stimuli such as pitch and loudness often correspond to dimensions of other modalities, for example, audio-visual and audio-spatial correspondences revealed that humans tend to match higher-pitched sounds with greater brightness, and lower-pitched sound with greater objects (Odgaard, Arieh, \&Marks, 2004; Spence 2011). Whether these correspondences are innate or learned from the cultural environment is still debated.

It has been found that crossmodal interaction (visual and aural) in the perception of musical stimuli leads participants to acquire a deeper understanding of the musical phenomena (Vines, Krumhansl, Wanderley, Dalca \& Levitin 2011; Kussner \& LeechWilkinson 2014).

The studies which have been cited so far suggest the role of movement and visualization in the elaboration of musical stimuli, and the close relationship between different codes has been further reinforced by neurological research.

Neuroscience studies further suggest that different portions of the brain are integrated and activated by the same stimuli. Zatorre (Chen, Penhune, and Zatorre 2008), analysing the fMRIs of listeners' brain, found that the activity of listening is processed mainly in the hearing area, but also involves the bodily-kinaesthetic area of the brain. Research has demonstrated that cross-modal interaction occurs when one stimulus processed by a sensory modality is influenced by a stimulus that is available in another sensory modality. A visual input can be observed in the auditory cortex and in the same way a visual and auditory input can be observed in the soma-sensory cortex. The multisensory nature of the brain offers human beings an advantage in learning activities (Zimmerman \& Lahav 2012).

\section{An overview of the role of body movements and visualization in music education methods}

Body movements and visualization have also been considered to be important vehicles for music education, and these learning modalities are used in methods such as those of Kodaly (1974), Orff (1950), Gordon (2003) and Dalcroze (1919). The last one emphasized the effect of body movements to feel and experience musical concepts. According to Dalcroze's method musical consciousness is the result of physical experience, and can be acquired by repeated auditory and vocal experiences, as well as movement of the body. In this way, all the features experienced with the whole body could be transferred to the musical instrument. According to the Dalcroze method, body movements create a link between ear and brain so as to improve the embodiment of musical features and expressivity on the instrument. The method is structured in three branches: eurhythmics, solfège, and improvisation, and all the activities focus on the claim that a deeper musical 
understanding is achieved when muscle and body movement are involved. Carl Orff used movements and choreography mainly to reproduce popular dances and to learn rhythmic patterns, and body percussion. The body has the function of a musical instrument, producing a number of different sounds. Different timbres are produced according to the part of the body used and the way that they are moved and struck against each other. For example, clicking one's fingers, clapping one's hands or striking the hand on the thigh. Body movement is used more freely in Gordon's method for young children. Other methods, on the other hand, focus mainly on the activity of visualization.

The process of visualization has two meanings. The first is the creation of external graphic representation by children or the activity of drawing map listening, and the second is observing a moving arm gesture that suggests a musical meaning.

Zoltan Kodaly, for example used mainly hand movements (i.e. hand signs) in the Tonic sol-fa system to teach musical pitch and rhythm. The different hand gestures, which were derived from the studies of John Curwen (1816-1880), address the visualization of the corresponding tonal functions of the notes. In a different way, in the method created by Justine Ward (1878-1975), the arm positions that move up and down, are used to indicate the scale grade according the tonic sol-fa system. In both methods, body movements and visualizations are addressed to describe the melodic profile to be sung. The analogy between gestures and intonation of the voice that rises and falls in pitch helps the learner to follow the correct melodic direction thanks to visualization of the gestures. The Chironomia (chiros - hand, nomos - rule), was introduced for the first time by Guido D'Arezzo in the Middle Ages and was reintroduced by Curwen in the nineteenth century, and used more recently by Kodaly.

The integration of different modalities: aural, visual, and kinaestetic represents the basic principles of the methods of C.Orff, J.J. Dalcroze, Z. Kodaly and J. Ward and are still considered in contemporary methodological principles. The fundamental idea is that of internalizing a musical image through all our senses, so as to build metaphoric (aural, verbal, visual, kinaesthetic) frames for understanding music and shaping a mental image of the sound features.

\section{Body movement, sound and symbolization, perspective in music education}

\footnotetext{
"Hearing is nothing else but a feeling of the tune or sound in this part, which accordingly, more or less, as it strikes our eare, makes the sound grave or harsh, sweet or displeasing: and if it strikes us too rudely or violently, then it not only touches the eare, but all the whole body, as when a great noyse or thunder makes all things tremble or shake under us, and seems to strike and astonish the foundations of houses by this sudden and violent feeling."
}

Léonard de Marandé, The Judgment of Humane Actions, trans. John Reynolds (London: Bourne, 1629), 35-36. 
As Léonard de Marandé argued in the seventieth century, we feel music with the whole body, not only by ear. This means that the body is involved through all its senses. In the same sense, the metaphor of body movement is a means to feel the movement of the sound when it goes fast or slow, moving toward a cadence or when reposing on a tonic, and when it moves up and down in a melodic profile.

We listen and react to music with the whole body, and this process allows human beings to understand music intellectually. In the specific environment of music education, musicians, through body movements can reinforce musical concepts kinesthetically and transfer force, rhythm, dynamics, and speed from the whole body movements to just specific parts of the body, and thereafter to the instrument. These statements give important insights to music education and instrument teaching. Children, for example, can walk to the steady beat of the piece they are singing to strengthen movement coordination and change direction when they feel that there is another musical phrase. In another experience they may describe the contrasts of intensity in the music using large or small movements of their feet, stepping with different strengths, so that psychomotor awareness can then be transferred to fine motor skills. In another situation, children could be encouraged to move their hands in the air to the music to find the accents, dynamics, and articulation or to shape the different phrases of the piece.

The sequences of body movements could be teacher-generated or learnergenerated (Kerchner 2014). In the former, the teacher proposes movements associated with the music, which can be imitated. In the latter, the movements, which describe the musical parameters (speed, rhythm, melody, and musical articulation of phrases), vary according to learners' knowledge and way of perceiving the music. Furthermore, the transposition between listening or performing and body movement could be enriched by the use of graphic representations. The chance to use different sensory modalities (visual, auditory, spatial and kinaesthetic) can help learners to more effectively process this content and become more responsible for their own knowledge.

The transposition of a visual code allows the learner to describe musical features in an analogic way that traditional staff notation would not allow; for example, they could draw different kinds of staccato, crescendo or rallentato.

Gromko (1994) found correlations between test results on perceptual discrimination, age, and children's invented notations, considering the activity of drawing a measure of their musical understanding. In some cases invented notations are a mirror of the mental image of the musical features, as in the following examples, in which different graphic notations of a child are a mirror of the perceptual discrimination of a rhythmic pattern after two months of musical training: 


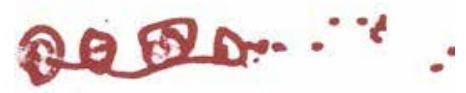

Figure 1. Five-year-old child's drawing of "rhythmic patterns"

Figure 2. Five-year-old child's drawing of "rhythmic patterns" after two months of music lessons

There is a reciprocal reinforcement between a musical idea and graphic symbolization when it is suggested that the learner should find a graphical code to draw the sound features. This kind of activity could give children a deeper awareness of the music they have heard (Kerchner 2014). In a recent study it was found that the effort to find an analogic correspondence between sound and sign allows children to refine their knowledge of musical features (Fortuna 2015). Beginner violinists were asked to explore a sound's length, volume, energy and articulation by using voice, movement and finally graphic symbols. The purpose of integrating these activities was to aid the transfer of musical concepts, such as contrasting loud/soft dynamics, or gradation of tone crescendo, diminuendo, or articulation of staccato/legato to the instrument, through the mediums of body, voice and sight. Some examples are shown below:

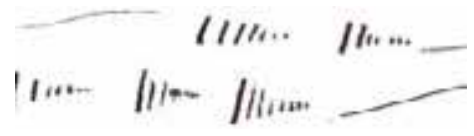

Figure 3. A child's picture of sounds in diminuendo

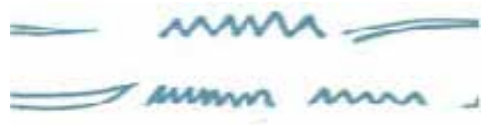

Figure 4. A child's picture of legato and staccato

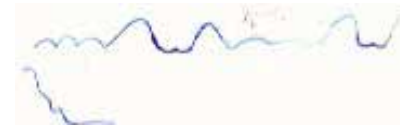

Figure 5. A child's picture of the first phrase of a melody 
This study revealed that turning music into body movements, singing and graphic symbolization could be a means for children to create a mental image of musical features. At present, music teachers recognize the utility of body movements and the spontaneous writing of children (Maerker Garner 2009, Manifold 2008, Barry 2008, Gault 2005). Recently, the integration of action-based activities and the process of visualization as an instrument for enriching and making the learning process more creative have been assessed. One of the projects which is moving in this direction is the Music Paint Machine, an interactive music system that allows musicians to make a digital painting by playing music and by moving on a coloured mat (Nijs \& Leman 2014, 2015). MIROR-Body gesture (Volpi, Vanni Addessi \& Mazzarino 2012, Vanni, Volpe, Segaleo, Mancini \& Lepre 2013), is an interactive, reflexive music system in which the perception of the sound produced by the system is a virtual copy of the child's movements (Addessi, Maffioli \& Anelli 2015).

\section{Conclusion}

We can conclude that an embodied way of learning and the challenge to find out an individual graphic symbolization could lead to a stronger mental image and psychomotor awareness of a musical experience. The learner can explore aural, visual, and kinaesthetic strategies to process conceptual learning. These modalities can be linked to Bruner's learning theory, which identifies three modalities of representation during the process of learning: enactive, iconic and symbolic representation: enactive representation in which there is an active-based interaction with music, after which an iconic representation, using images, is formed, and finally, symbolic representation, which is the understanding of traditional music notation and language. Using these modalities, teaching becomes closer to children's natural way of learning, in which the body and imagination are connected.

We have to consider the fact that a multimodal method of learning and the different transpositions between the body, sound and visual representations are focused on synesthetic and kinematic sensations of sounds. The present study underlines that integrating body movement, aural images and visualizations, in a multisensory approach, could give a new perspective to music education. 


\section{REFERENCES:}

1. Abril, Carlos. R. 2011. "Music, movement and learning". In MENC Handbook of Research on Music Learning (Vol. 2, pp. 92-129), Edited by R. Colwell \& P. Webster. New York, NY: Oxford University Press.

2. Addessi, Anna.R.; Maffioli, Marina.; Anelli, F. 2015, "The MIROR platform for young children's music and dance creativity. Reflexive interaction meets body-gesture, embodied cognition, and Laban educational dance". In Perspectives, 10, 9 - 18.

3. Bamberger, Jeanne. 1982. "Revisiting children's drawings of simple rhythms: A function of reflection in action”. In U-shaped behavioural growth edited by S. Strauss \& R. Savy. 191226. New York: Academic Press.

4. Bamberger, Jeanne. 1991. The mind behind the musical ear. How children develop musical intelligence. Cambridge, MA: Harvard University Press.

5. Barrett, Margaret. 2002. "Invented notations and mediated memory: A case-study of two children's use of invented notations". Bulletin of the Council for Research in Music Education, 153(4), 55-62.

6. Barry, Nancy B. 2008. "The Role of Integrated Curriculum in Music Teacher education". Journal of Music Teacher Education, 18 (1) 28-38.

7. Chen Joyce L., Penhune, Virginia B., \& Zatorre Robert J. 2008. "Moving on Time: Brain Network for Auditory-Motor Synchronization is Modulated by Rhythm Complexity and Musical Training". In Journal of Cognitive Neuroscience 20:2, 226-239.

8. Davidson, Jane W. 2005. "Bodily communication in musical performance". In Musical communication, edited by D. Miell, R. Macdonald, \& D. J. Hargreaves 215-238. New York, NY: Oxford University Press.

9. Davidson, Jane. 2012. "The Role of Bodily Movement in Learning and Performing Music: Applications for Education". In The Oxford Handbook of Music Education, edited by G. E. McPherson \& G. F. Welch,Vol.1 Oxford: Oxford University Press.

10. Davidson, Lyle. \& Scripp, Larry. 1988. "Young children's music representation: windows on music cognition”. In Generative processes in music. Edited by J. Sloboda. Oxford: Oxford.

11. Curwen John. 1892. The Standard Course of Lessons and exercises in the Tonic Sol-fa Method of Teaching Music.(10 ${ }^{\text {th }}$ ed.) London: J. Curwen \& Sons.

12. Eerola Tuomas, Luck Geoff, Toiviainen Petri. 2006. "An investigation of pre-schoolers' corporeal synchronization with music”. In: Proceeding. International Conference on Music Perception \& Cognition (ICMPC). Bologna, Italy, 472-476.

13. Galvao, Afonso, \& Kemp, Anthony. 1999. "Kinesthesia and instrumental music instruction: some implications". Psychology of Music, 27(2), 129-137.

14. Gardner, Howard. 1982. Frames of Mind: The Theory of Multiple Intelligences (2nd edition). New York: Basic Books.

15. Gault, Brent. 2005. Music learning through all the channels: combining aural, visual, and 
kinesthetic strategies to develop musical understanding. General Music Today (Online) 19(1), $7-9$.

16. Gordon, Edwin. 2003. A Music Learning Theory for Newborn and Young Children. Chicago, IL: GIA.

17. Gromko, J. E. 1994. Children's invented notation as measures of musical understanding. Psychology of Music, 22, 136-147.

18. Gromko, J., \& Poorman, A. 1988. Development trends and relationships in children's aural perception and symbol use. Journal of Research in music education 46(1),16-23.

19. Juntunen, Marja. L. \& Westerlund, Heidi. 2001. "Digging Dalcroze, or, dissolving the mindbody dualism". Music Education Research, 3 (2) 203-214.

20. Juntunen, Maria. L., \& Hyvönen, Leena. 2004. "Embodiment in musical knowing: How body movement facilitates learning within Dalcroze eurhythmics". British Journal of Music Education, 21 (2), 199-214.

21. Kerchner, Jody. L. 2014. Music across the sensess. Oxford: Oxford University Press.

22. Kodály, Zoltan. 1974. The Selected Writings of Zoltán Kodály. (L. Halápy and F. Macnicol trans.). London: Boosey \& Hawkes.

23. Kozak, Mariusz. 2015. "Listeners' Bodies in Music Analysis: Gestures, Motor Intentionality, and Models". Society for Music Theory. Volume 21, 9.

24. Kussner, Mats B., \& Leech-Wilkinson, Daniel. 2014. "Investigating the Influence of Musical Training on Cross-Modal Correspondences and Sensorimotor Skills in a Real-Time Drawing Paradigm". Psychology of Music. 42(3):448-469.

25. Leman, Marc. 2008. Embodied music cognition and mediation technology. Cambridge, Mass., MIT Press.

26. Leman, Marc. 2010. An Embodied Approach to Music Semantics. Musicae Scientiae, Discussion Forum 5: 43 - 67.

27. Maerker Garner, Allison. 2009. "Singing and Moving: Teaching Strategies for Audiation in Children". Music Educators Journal, 95,(4), 46-50.

28. Maes, Pieter-Jan, Leman, Marc. 2013. “The Influence of Body Movements on Children's Perception of Music with an Ambiguous Expressive Character". PLoS One, 8(1).

29. Manifold, Lorreine H. 2008. Applying Jaques-Dalcroze's method to teaching musical instruments and its effect on the learning process, online.

30. Marandé de Léonard "The Judgment of Humane Actions”, trans. John Reynolds (London: Bourne, 1629). In Music Education in the Middle Ages and the Renaissance, edited by Susan Forscher Weiss, Russell E. Murray 35-36. Bloomington: Indiana University Press.

31. Merleau-Ponty, Maurice. 1962. Phenomenology of Perception.London: Routledge \& Kegan Paul, 1962; rev. 1981.

32. Nijs, Luc.,\& Leman, Marc. 2014. "Interactive technologies in the instrumental music classroom: a longitudinal study with the music paint machine". Computer \& Education 73, 40-59. 
33. Nijs, Luc.,\& Leman, Marc. 2015. "Performing with the Music Paint Machine: provoking an embodied approach to educational technology". In Music, Technology \& Education: Critical Perspective, edited by A. King \& E. Himonides. London: Ashgate Psychology of Music Series.

34. Orff, Carl. \& Keetman, Gunild. 1950. Musik für Kinder, voll. I-V, Mainz, Schott's Söhne.

35. Phillips-Silver, Jessica, \& Trainor, Laurel J. 2007. "Hearing what the body feels: Auditory encoding and rhythmic movement". Cognition 105: 533-546.

36. Phillips-Silver, Jessica, \& Trainor, Laurel J. 2007. "Feeling the beat: movement influences infant rhythm perception". Science. Jun 3; 308 (5727):1430.

37. Spence, Carles. 2011. "Crossmodal correspondences: a tutorial review". Attention, Perception, \& Psychophysics. ;73:971-995.

38. Tomlinson, Michelle. 2013. "Literacy and music in early childhood: multimodal learning and design". SAGE Open, July/September, 1-10.

39. Upitis, Rena. 1992. Can I play you my song? Portsmouth, N.H.: Heinemann.

40. Verschaffel Lieven, Reybrouck, Marc, Janssens, Marian, \& Van Dooren, Wim. 2009. "Using graphical notations to assess children's experiencing of simple and complex musical fragments". Psychology of Music,38, 259 -284.

41. Vines, Bradley W., Krumhansl, Carol L., Wanderley Marcelo M., Dalca, Ioana M.,Levitin Daniel. J. 2011. "Music to my eyes: Cross-modal interactions in the perception of emotions in musical performance". Cognition (118).157-170.

42. Vygotskij, Lev S. 1990. Immaginazione e creatività nell'età infantile. Roma: Editori Riuniti.

43. Volpe G.; Varni G.; Mazzarino B.; Addessi Anna R., 2012. "BeSound: Embodied reflexion for music education in childhood", in Proceedings 11th International Conference on Interaction Design and Children, Bremen, UNK, Germany, June 12 - 15pp. 172 - 175.

44. Werner Heinz, \& Kaplan Bernard.1963. Symbol formation. Hillsdale: Lawrence Erlbaum Associates.

45. Zbikowski, Lawrence. 2008. "Metaphor and Music". In The Cambridge Handbook of Metaphor and Thought, edited by R. W. Gibbs, Jr, 502-524. Cambridge. UK: Cambridge University Press.

46. Zimmerman,Emily, \&Lahav,Amir 2012. "The multisensory brain and its ability to learn music". Annals of the New York Academy of Sciences.New York: Academy of Sciences, 17984. 


\section{Otelovljenje, zvuk i vizualizacija: multimodalna perspektiva u muzičkom obrazovanju}

Apstrakt: Mnoge studije su nedavno ukazale na ulogu pokreta tela u procesiranju, deljenju i davanju značenja muzike. Istovremeno, istraživanja neuronauke sugerišu da su različiti delovi mozga uključeni i aktivirani istim stimulansima: zvuci, na primer, mogu biti percipirani dodirom i mogu prizvati sliku, energiju, fluentnost i periodičnost. Ovakva interakcija auditivnih, vizuelnih i motornih osećaja može se naći u verbalnim opisima muzike i kod dece tokom njihovih spontanih igara. Pitanje koje se mora postaviti je da li bi višesenzorni i otelovljeni pristup mogao da redefiniše neka naša shvatanja o muzičkom obrazovanju. Nedavna istraživanja o otelovljenju i višemodalnoj percepciji u instrumentalnoj nastavi možda nagoveštavaju nove pravce u muzičkom obrazovanju. Možemo li smatrati da je integracija aktivnosti u kojima su uključeni pokreti tela, slušanje, metafore vizualizacije i pevanje efektnija za proces razumevanja muzike nego pristup koji je neotelovljen i fragmentovan?

Ključne reči: otelovljenje, višemodalno učenje, vizualizacija, muzičko obrazovanje, pokret tela 